\title{
Impact Evaluation of a Slush Stock Chest Bypass Installed at Scott Paper Company Under the Energy \$avings Plan
}

\author{
M. A. Oens \\ G. E. Spanner
}

February 1995

Prepared for Sheila Riewer Program Evaluation Section Office of Energy Resources Bonneville Power Administration the U.S. Department of Energy under Contract DE-AC06-76RLO 1830

Pacific Northwest Laboratory Richland, Washington 99352 


\title{
DISCLAIMEF
}

This report was prepared as an account of work sponsored by an agency of the United States Government. Neither the United States Government nor any agency thereof, nor Battelle Memorial Institute, nor any of their employees, makes any warranty, expressed or implied, or assumes any legal liability or responsibility for the accuracy, completeness, or usefulness of any information, apparatus, product, or process disclosed, or represents that its use would not infringe privately owned rights. Reference herein to any specific commercial product, process, or service by trade name, trademark, manufacturer, or otherwise does not necessarily constitute or imply its endorsement, recommendation, or favoring by the United States Government or any agency thereof, or Battelle Memorial Institute. The views and opinions of authors expressed herein do not necessarily state or reflect those of the United States Government or any agency thereof.

\author{
PACIFIC NORTHWEST LABORATORY \\ operated by \\ BATTELLE MEMORIAL INSTITUTE \\ for the
}

UNITED STATES DEPARTMENT OF ENERGY

under Contract DE-ACO6-76RLO 1830 


\section{DISCLAIMER}

Portions of this document may be illegible in electronic image products. Images are produced from the best available original document. 


\section{Summary}

This impact evaluation of the bypass of a slush stock chest that was recently installed at Scott Paper Company (Scott Paper) was conducted for the Bonneville Power Administration (Bonneville) as part of an evaluation of its Energy \$avings Plan (E\$P) Program. The project consists of installing an adjust- . able speed drive, a $74.6 \mathrm{~kW}$ (100 hp) pump, a re-sized impeller, and piping modifications to bypass the slush stock chest and related equipment. The objective of this impact evaluation was to assess how much electrical energy is being saved at Scott Paper as a result of the E\$P and to determine how much the savings cost Bonneville and the region. The impact of the project was evaluated with a combination of engineering analysis, financial analysis, interviews, and submittal reviews (Scott Paper's proposal and completion report).

Based on this impact evaluation, 'energy savings from this project are expected to be 763,600 kilowatt-hours/year ( $\mathrm{kWh} / \mathrm{yr}$ ) or 0.087 average megawatts (aMW). On a per-ton basis, this project will save $4.64 \mathrm{kWh} /$ ton or $39.2 \%$. The project cost $\$ 120,098$ to install, and Scott Paper received payment of $\$ 82,232$ (in 1993 dollars) from Bonneville for the acquisition of energy savings. Pacific Northwest Laboratory calculated the real levelized cost of the energy savings to Bonneville as 14.2 mills/kWh (in 1993 dollars) over the project's assumed 15-year life, and the real levelized cost to the region as 21.9 mills $/ \mathrm{kWh}$, not including transmission and distribution effects. The project would not have been implemented without the acquisition payment from Bonneville and therefore is not a free rider. 


\section{Contents}

Summary $\ldots \ldots \ldots \ldots \ldots \ldots \ldots \ldots \ldots \ldots \ldots \ldots \ldots \ldots \ldots \ldots$, iii

1.0 Introduction $\ldots \ldots \ldots \ldots \ldots \ldots \ldots \ldots \ldots \ldots \ldots \ldots \ldots \ldots \ldots$

1.1 Approach for Impact Evaluation $\ldots \ldots \ldots \ldots \ldots \ldots \ldots \ldots \ldots .2$

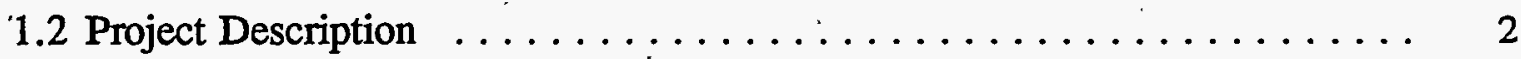

1.3 Summary of Project Impacts $\ldots \ldots \ldots \ldots \ldots \ldots \ldots \ldots \ldots \ldots$

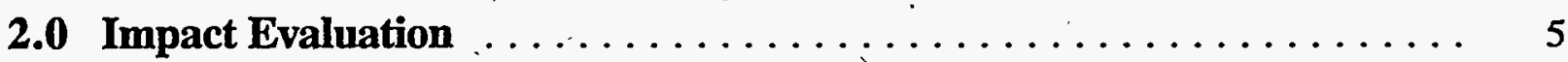

2.1 Energy Savings and Fuel Switching $\ldots \ldots \ldots \ldots \ldots \ldots \ldots \ldots \ldots$

2.2 Impacts to the Firm $\ldots \ldots \ldots \ldots \ldots \ldots \ldots \ldots \ldots \ldots \ldots \ldots$

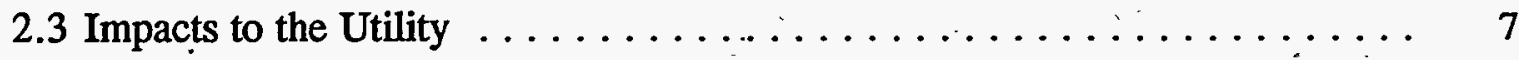

2.4 Real Levelized Costs $\ldots \ldots \ldots \ldots \ldots \ldots \ldots \ldots \ldots \ldots \ldots \ldots .7$

2.4.1 Bonneville Perspective $\ldots \ldots \ldots \ldots \ldots \ldots \ldots \ldots \ldots \ldots \ldots \ldots, 7$

2.4.2 Regional Perspective $\ldots \ldots \ldots \ldots \ldots \ldots \ldots \ldots \ldots \ldots \ldots .8$

2.5 Impact Attributable to $\mathrm{E} \$ \mathrm{P} \ldots \ldots \ldots \ldots \ldots \ldots \ldots \ldots \ldots \ldots \ldots$

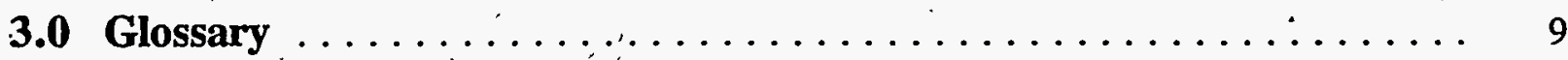

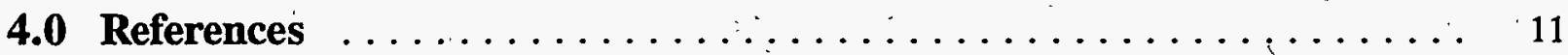

Appendix A - Financial Evaluation Details $\ldots \ldots \ldots \ldots \ldots \ldots \ldots \ldots$ A.1

Appendix B - Cover Sheets from Scott Paper's Project Proposals . . . . . . B.1 


\subsection{Introduction}

This report describes Pacific Northwest Laboratory's (PNL's) ${ }^{(a)}$ evaluation of the impact of an . energy conservation project installed in August 1993 at Scott Paper Company (Scott Paper) in Everett, Washington. The project at Scott Paper is one in a continuing series of industrial energy conservation projects to have its impact evaluated by PNL. All of the projects have received or will receive acquisition payments from the Bonneville Power Administration (Bonneville) under the Energy \$avings Plan (E\$P) Program.

The E\$P is being offered to reduce electrical energy consumption in the industrial sector of Bonneville's service territory. For the Scott Paper project, the acquisition payment offered under the program was equal to the lesser of $15 \mathrm{c} /$ kilowatt-hour $(\mathrm{kWh})$ saved in the first year or $80 \%$ of eligible project costs.

The general objective of the impact evaluation was to determine how much electrical energy is saved by the project and at what cost to Bonneville and to the region. In support of this general objective,_answers were sought to the following questions:

1. How much electrical energy is saved annually by the energy conservation project in terms of kilowatt-hours, kilowatt-hours per unit of plant output (unit savings), and average megawatts (aMW)? Also, did any fuel switching result from implementing this project?

2. If the project improved the productivity of the process, did the firm then increase output of the process to take advantage of the productivity improvement? Did the change in output result in a net increase or decrease in energy used by the process? , Did the change in output cause changes in output at the firm's other plants in the region?.

3. What was the net impact to the serving utility in terms of electrical energy consumption (in kilowatt-hours) from implementing the project?

4. What are the real levelized costs of the project from the perspectives of Bonneville and the region?

5. How much of the project's savings can be attributed solely to the E\$P?

(a) Pacific Northwest Laboratory is operated for the U.S. Department of Energy by Battelle Memorial Institute under Contract DE-AC06-76RLO 1830. 


\subsection{Approach for Impact Evaluation}

Before selecting individual energy conservation projects for evaluation, PNL developed a general impact evaluation methodology (Spanner et al. 1988). The major finding of the methodology development was that in the industrial sector, energy conservation projects must be evaluated on a case-by-case basis. Accordingly, the general methodology consists of a. variety of impact evaluation techniques that can be applied to individual projects according to the specific circumstances.

To evaluate the impact of bypassing the slush stock chest at Scott Paper, four techniques were selected from the general methodology: engineering analysis, financial analysis '(see Appendix A), site visit and interview, and review of Scott Paper's submittals. Submetering performed by Scott Paper in accordance with E\$P program requirements was relied upon by PNL to determine the project's impact. Representatives from PNL visited Scott Paper on January 26, 1994, to view the project firsthand and to interview the project leader and project engineer. .

\subsection{Project Description}

Scott Paper produces a variety of paper products ranging from toilet paper to industrial-strength paper towels. Scott Paper takes raw materials (wood along with other miscellaneous material) and blends them in a process to make pulp that is placed on screens at the correct thickness, then dried, and pressed to produce the desired product.

The energy conservation project at Scott Paper bypassed the slush stock chest, its agitator, and outlet pump. The slush stock chest was a holding tank for excess stock flowing to a critical process. Stock held in the slush stock chest was pumped as needed to a blend chest. With the advent of adjustable speed drives (ASDs) and better controls, the slush stock chest with its $44.7 \mathrm{~kW}$ (60-hp) agitator and $55.9 \mathrm{~kW}(75-\mathrm{hp})$ outlet pump could be bypassed. This will save energy by eliminating the use of the agitator and outlet pump. The pump and motor assembly just upstream of the shush stock chest was increased from $55.9 \mathrm{~kW}(75-\mathrm{hp})$ to $74.6 \mathrm{~kW}(100-\mathrm{hp})$ and was fitted with an ASD and controls to "fine tune" the flow of stock to the blend chest and other critical processes. Although the total throughput is not expected to change, the larger pump will allow a greater margin of safety for occasional flow problems in this stage of the process. Modifications were also made to the piping to bypass the slush stock chest, and a valve to adjust the level of pulp in the blend chest was added. This bypass can be seen in Figure 1.1. 


\section{Before}
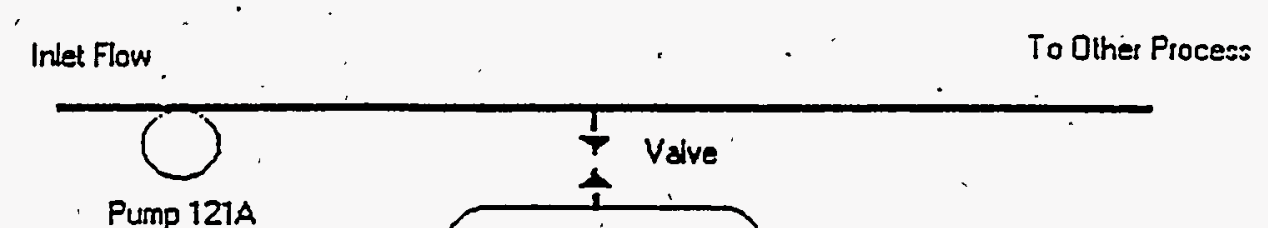

Pump 121A

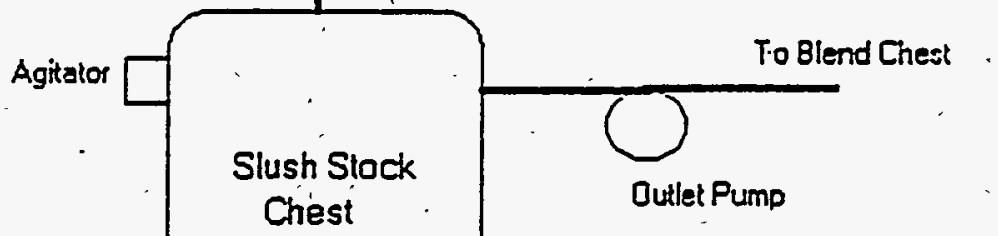

After

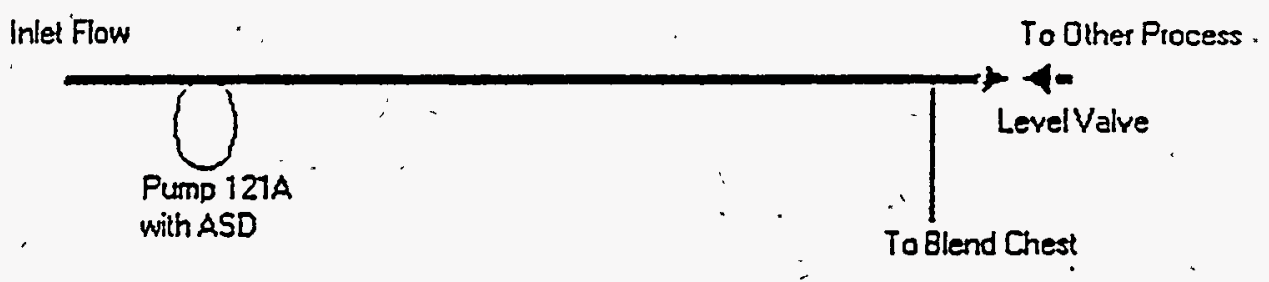

Figure 1.1: Bypass of Slush Stock Chest

For the energy conservation project at Scott Paper, two documents were submitted to Bonneville: a proposal and a completion report. The proposal described the energy conservation project and presented Scott Paper's cost and benefit expectations. Included was a calculation of the project's expected simple payback. A completion report was submitted to Bonneville after the project was installed and Scott Paper had verified the resulting energy savings. This document listed the actual costs of the project along with a calculation of the energy savings that had been achieved. A copy of the cover sheet from the proposal is included in Appendix B.

The total cost to install this project was $\$ 120,098$ and Bonneville paid $\$ 82,232$ for the energy saved. The acquisition payment was capped by Snohomish County PUD's contract with Scott Paper. The payment was calculated by multiplying the estimated cost $(\$ 108,200)$ by $80 \%$ and the contractor cost share.

Method: Estimated Cost $*$ Contractor Cost Share $* 80 \%=$ Acquisition Payment

Actual: $\$ 108,200 * .95 * .8=\$ 82,232$ 


\subsection{Summary of Project Impacts}

This E\$P project is expected to save 763,600 kilowatt-hours annually or 0.087 average megawatts. Over the assumed 15-year life of this project, the levelized cost to Bonneville is $14.2 \mathrm{mills} / \mathrm{kWh}$ (1 mill $=1 / 1000$ of a dollar), and the cost to the region is 21.9 mills $/ \mathrm{kWh}$. These costs are in real 1993 dollars and do not include additional savings that accrue if transmission and distribution losses are considered. The levelized cost to Bonneville including transmission and distribution losses is $13.2 \mathrm{mills} / \mathrm{kWh}$, and the cost to the region is $20.4 \mathrm{mills} / \mathrm{kWh}$.

Without the acquisition payment from Bonneville, this project did not meet Scott Paper's funding criteria; however, it did meet the criteria with the acquisition payment. Therefore, we conclude that it would not have been installed in the absence of the E\$P. 


\subsection{Impact Evaluation}

\subsection{Energy Savings and Fuel Switching}

How much electrical energy is saved annually by the project in terms of kilowatt-hours, kilowatthours per unit of plant output, and average megawatts? Also, did any fuel switching result from implementing this project?

\section{Energy Savings}

The energy savings was determined by the difference in power consumption before and after bypassing the slush stock chest. To determine the energy consumption of the motors and agitator; premetering and post-metering were performed. The inlet pump, outlet pump, and the agitator were all time-series metered for two weeks previous to the plant shut down. After the upgrade only the inlet pump was time-series metered for two weeks. The agitator and outlet pump were no longer in use and therefore, no metering was performed on this equipment.

Savings were calculated by computing a ratio of $\mathrm{kWh}$ to tons of material processed per day. The after-installation ratio was subtracted from the before-installation ratio, then multiplied by the daily production level, and the days of operation per year, which gave yearly savings in $\mathrm{kWh}$. The methodology and actual savings calculations are as follows:

Method:

$\left[\frac{\mathrm{kWh} / \text { day }}{\mathrm{Mg} / \text { day }}\right.$ (before) $-\frac{\mathrm{kWh} / \text { day }}{\mathrm{Mg} / \text { day }}$ (after) $] \times \mathrm{Mg} /$ day $\times$ days $/ \mathrm{yr}=$ Savings $\mathrm{kWh} / \mathrm{yr}$

\section{Actual:}

$\left[\frac{3374.4 \mathrm{kWh} / \text { day }}{401.3 \mathrm{Mg} / \text { day }}-\frac{1312.8 \mathrm{kWh} / \text { day }}{398.3 \mathrm{Mg} / \text { day }}\right]$ x $417.3 \mathrm{Mg} /$ day $\times 358 \mathrm{days} / \mathrm{yr}=763,600 \mathrm{kWh} / \mathrm{yr}$ 
PNL obtained more detailed information about production levels and yearly schedules than was reported in the completion report. The long-run production level is expected to be $417.3 \mathrm{Mg} /$ day (460 tons/day) and operating schedule is expected to be 358 days per year. PNL calculated the energy savings to be $763,600 \mathrm{kWh} / \mathrm{yr}(0.087 \mathrm{aMW})$.

The reason for the difference with the completion report is because the completion report assumed a lower production rate $17.2 \mathrm{Mg} /$ day (19.3 tons/day lower) and fewer days of operation per year ( 8 days/year fewer). On a per-ton basis, this project will save $5.11 \mathrm{kWh} / \mathrm{Mg}(4.64 \mathrm{kWh} / \mathrm{ton})$, which is a reduction of approximately $39 \%$. Tablé 2.1 shows the installation cost and energy savings as reported in the completion report and impact evaluation.

Table 2.1. Installation Costs and Energy Savings

\begin{tabular}{||c|c|c|}
\hline \multicolumn{1}{|c|}{ Source } & Energy Savings (kWh) & Installation Costs \\
\hline Completion Report & 715,203 & $\$ 120,098$ \\
\hline Impact Evaluation & 763,600 & $\$ 120,098$ \\
\hline
\end{tabular}

\section{Fuel Switching}

Because electric motors are the most economical prime movers for pumps of this size, fuel switching was not a feasible option, so no fuel switching occurred.

\subsection{Impacts to the Firm}

If the project improved the productivity of the process, did the firm then increase output of the process to take advantage of the productivity improvement? Did the change in output result in a net increase or decrease in energy used by the process? Did the change in output cause changes in output at the firm's other plants in the region?

Installation of this project improved the productivity of this process by reducing the amount of energy required. The plant already operates at its maximum capacity, however, so this project will not result in any changes in production levels. Scott Paper has no other plant that produces similar products in the region, so no impacts will occur at other plants. 


\subsection{Impacts to the Utility}

What is the net impact to the serving utility in terms of electrical energy consumption (in kilowatt-hours) from implementing the project?

Because the project has no co-generation or other complicating factors, all of the energy savings from this project will be reflected in reduced load at the utility. The net impact to the serving utility from this project is a reduction in electrical energy consumption of $763,600 \mathrm{kWh} / \mathrm{yr}$. A co-generation plant is being added, but all of the power produced will belong to Snohomish County PUD.

\subsection{Real Levelized Costs}

What are the real levelized costs of the project from the perspectives of Bonneville and the region?

Real levelized annual costs are used to compare the attractiveness of various projects or investment alternatives. The levelized cost is the annual cost that would be incurred over the life of a project, accounting for the time value of money (see Appendix A for complete definitions and formula). Levelized costs provide a single figure of merit for comparing energy conservation alternatives. In addition, levelized costs can be used to compare conservation projects with options for new generating capacity and to optimize the ranking of these options. Levelized costs are calculated from the perspectives of Bonneville and the region (Bonneville and Scott Paper combined).

In the industrial sector, it is not possible to accurately predict the life of a project because any number of external factors could cause the project to have longer or shorter life than expected when it is installed. To allow comparisons of levelized costs among projects installed under the E\$P, all projects are assumed by. PNL (for evaluation purposes) to have a life of 15 years. Even though some projects will have longer or shorter lives, 15 years is considered a conservative, but likely, life for typical projects in the industrial sector.

\subsubsection{Bonneville Perspective}

To determine the real levelized costs to Bonneville and to the region, we must know the project costs (acquisition payment, capital costs, etc.) and the energy savings, and we must assume a discount rate and project life. With energy savings of $763,600 \mathrm{kWh} / \mathrm{yr}$, the project's levelized cost from 
Bonneville's perspective is 14.2 mills/kWh (in 1993 dollars; see Appendix A). Bonneville's levelized cost decreases to $13.2 \mathrm{mills} / \mathrm{kWh}$ when transmission and distribution losses are considered. Including these losses allows for the comparison of conservation resources with generation, which is measured at the point of production rather than at the site of the end user (point of delivery).

The levelized costs calculated in this impact evaluation-include the acquisition payment by Bonneville as well as the estimated administrative and evaluation costs associated with this project.

\subsubsection{Regional Perspective}

To calculate the real levelized cost to the region, the costs to Bonneville and Scott Paper are combined. The acquisition payment by /Bonneville is included as a cost to Bonneville and as a reduction in cost to Scott Paper. This approach is taken because the acquisition payment has federal income tax consequences for the company and, therefore, is not a net zero-cost to the region.

The calculated, real, levelized cost to the region for acquiring annual energy savings of $763,600 \mathrm{kWh}$ is 21.9 mills/kWh saved. Including transmission and distribution losses, the levelized cost decreases to 20.4 mills/kWh saved.

\subsection{Impact Attributable to $\mathbf{E} \$ P$}

\section{How much of the project's impact can be attributed to the E\$P?}

Scott Paper uses simple payback to select plant improvement projects, but it does not have a predetermined payback that a project must meet for implementation. When this project was proposed to Bonneville, it was expected to cost $\$ 108,200$ and result in electrical savings of $\$ 17,397 / \mathrm{yr}$ (usage and demand savings combined), for a simple payback of about 6.2 years based solely on energy savings. However, according to the project leader, the firm's primary reason for installing this slush stock chest bypass was to obtain energy savings. Considering the facts presented above, we conclude that this project would not have been implemented without the acquisition payment from Bonneville and that all of the project's impact can be attributed to the E\$P. Therefore, the project is not a free rider. 


\subsection{Glossary}

pump motor assembly - : includes pump motor, head, impeller and all associated equipment.

slush stock chest.

- is a tank constructed of cement and rebar. The tank holds excess stock flowing to a critical process. 


\subsection{References}

Spanner, G. E., D. R. Brown, D. R. Dixon, B. A. Garrett, R. W. Reilly, J. M. Roop, and S. A. Weakley. 1988. Potential Techniques for Evaluating the Impact of Industrial Energy Conservation Projects under Bonneville's Energy \$avings Plan. Letter Report. PNL-6628, Pacific Northwest Laboratory, Richland, Washington. 
Appendix A

\section{Financial Evaluation Details}




\section{Appendix A}

\section{Financial Evaluation Details}

\section{A.1 Definitions}

Real Levelized Cost - A single figure of merit that expresses the cost per unit of benefit (in this case, energy savings), accounting for the time value of money. This annualized cost (not the "adjusted system real levelized cost") would be constant over the entire project life. An infinite number of cash flow scenarios (costs incurred at different times in the project life) could result in the same annualized cost.

Real Levelized Cost to Bonneville Power Administration (Bonneville) - The annualized costs to Bonneville, direct and indirect, per unit of energy saved by the energy conservation project. Costs included are the acquisition payment and the program administrative costs, as well as the costs to evaluate the impact of this project.

Real Levelized Cost to the Region - The sum of annualized costs to Bonneville, and Scott Paper per unit of energy saved by the energy conservation project. This would include the same costs to Bonneville as listed above, as well as the initial capital and ongoing incremental production costs to the firm. Any non-electrical savings that result from the project are not considered in this analysis.

\section{A.2 Real Levelized Cost Formula}

$$
\begin{gathered}
\mathrm{LC}=\{\mathrm{PVCI}+\mathrm{PVICI}+(\mathrm{PVOM}+\mathrm{PVOTE}) \bullet(1-\mathrm{itf})-\mathrm{PVD} \bullet \mathrm{itf}] \\
/(1-\mathrm{itf})\} \bullet(\mathrm{CRF} / \mathrm{AES})
\end{gathered}
$$

where $\quad L C=$ levelized cost $(\mathrm{real} \$)$

PVCI = present value of initial capital costs

PVICI $=$ present value of interim capital costs

PVOM = present value of operating and maintenance costs

PVOTE $=$, present value of one-time expenses 


$$
\begin{aligned}
\text { itf } & =\text { combined state and federal income tax fraction } \\
\text { PVD } & =\text { present value of depreciation } \\
\mathrm{CRF} & =\text { capital recovery factor (spreads the costs over the project life in real-dollar terms) } \\
\mathrm{AES} & =\text { annual energy savings }(\mathrm{kWh} / \mathrm{yr})
\end{aligned}
$$

\section{A.3 General Assumptions}

The following general assumptions were made in the real levelized cost calculations:

1. All cash flows are expressed in nominal terms (with infiation) and are discounted to present value at a nominal discount rate of $7.12 \%$ (combines a real discount rate of $3.0 \%$ and an inflation rate of $4.0 \%)$. The costs are annualized over the life of the project using the capital recovery factor at a real discount rate of $3.0 \%$, resulting in real levelized costs.

2. Annual energy savings $(\mathrm{kWh} / \mathrm{yr})$ are constant over the 15 -year life of the project. This assumes no loss in efficiency of the equipment with time.

3. Transmission and distribution losses equal $7.5 \%$, increasing the energy savings at the source (point of generation) by a corresponding $7.5 \%$.

4. In the regional cost calculation, the acquisition payment from Bonneville is treated as a cost to Bonneville and, at the same'time, as a cash inflow to Scott Paper rather than a net-zero cost. This is done because Scott Paper will incur a tax liability from the acquisition payment, thus incurring a net cost to the region.

\section{A.4 Bonneville Levelized Cost Calculations}

Input: one-time expenses

Acquisition payment paid (year 1)

$=\$ 82,232$

Administrative and evaluation costs (years 0 and 1)

$=\$ 8,223$

Tax rate

$=0 \%$

Annual energy savings

$=763,600 \mathrm{kWh}$

Output: levelized cost

$=14.2$ mills $/ \mathrm{kWh}$ 


\section{A.5 Regional Levelized Cost Calculations (Bonneville + Scott Paper)}

A. Scott Paper

Input: initial capital (year 0)

Equipment

$=\$ 120,098$

One-time expenses (revenues - year 1)

Acquisition payment received

$$
=(\$ 82,232)
$$

Tax rate

$=34 \%$

Project life

$=15$ years

Depreciation

$=7$ years

Annual energy savings

$=763,600 \mathrm{kWh}$

Output: levelized cost

$=7.7 \mathrm{mills} / \mathrm{kWh}$

B. Regional levelized cost $=$ Bonneville levelized cost + Scott Paper levelized cost

$$
\begin{aligned}
& =14.2 \text { mills } / \mathrm{kWh}+7.7 \text { mills } / \mathrm{kWh} \\
& =21.9 \mathrm{mills} / \mathrm{kWh}
\end{aligned}
$$

\section{A.6 Levelized Costs Allowing for Transmission and Distribution Losses}

Input: 'transmission and distribution losses

$$
=7.5 \%
$$

Bonneville levelized cost $=14.2 \mathrm{mills} / \mathrm{kWh} / 1.075=13.2 \mathrm{mills} / \mathrm{kWh}$

Regional levelized cost $\quad=21.9 \mathrm{mills} / \mathrm{kWh} / 1.075=20.4 \mathrm{mills} / \mathrm{kWh}$ 
Appendix B

Cover Sheets from Scott Paper's Project Proposal 


\section{Appendix B}

\section{Cover Sheets from Scott Paper's Project Proposal}

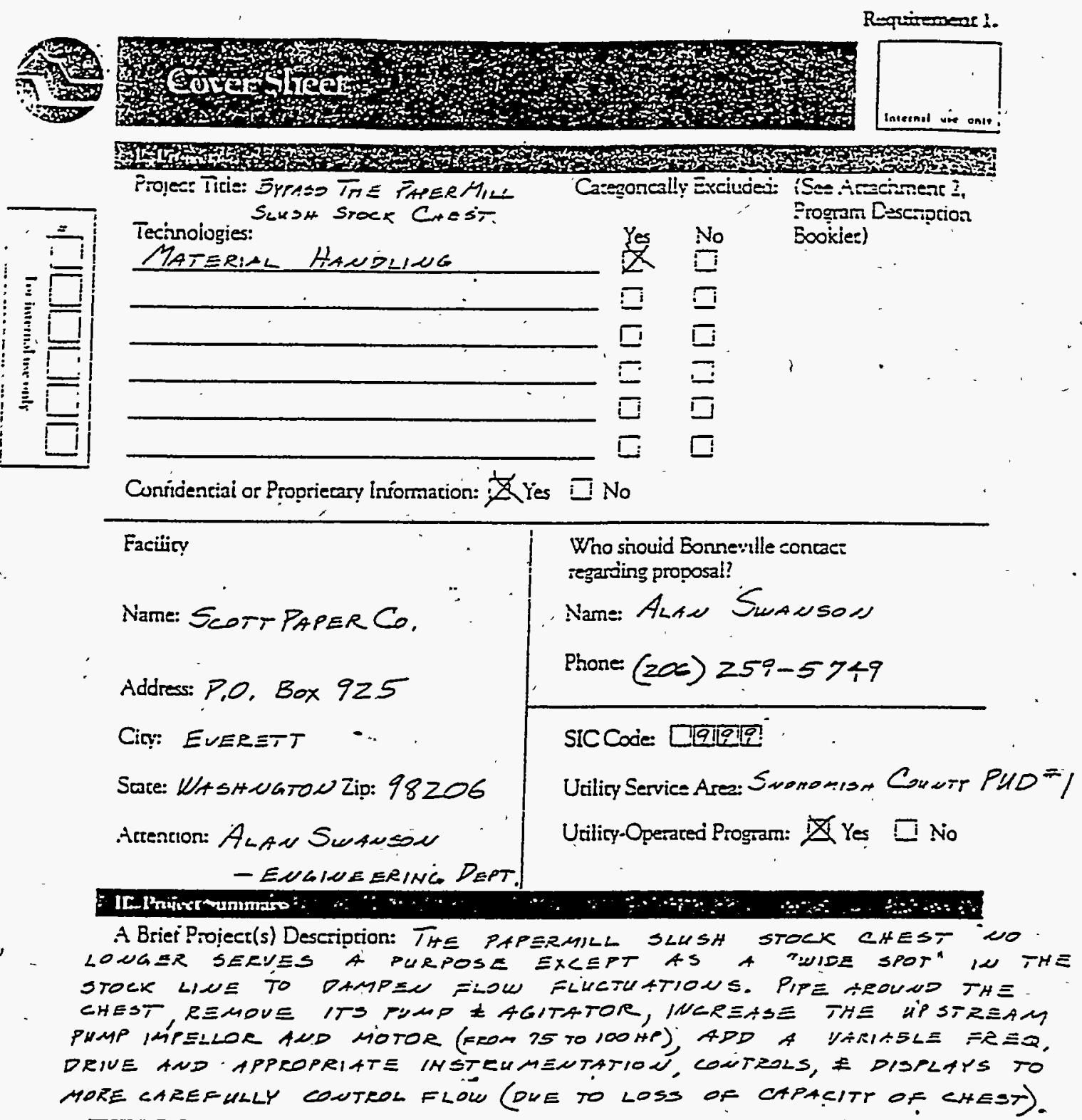

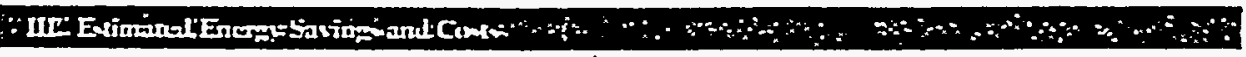

Average Annual Energy Savings:

$$
664 \mathrm{MWH} / \mathrm{RR}
$$

Estımated Incentrve:

$$
\$ 82,232
$$

(see atrachment " $B$ ")
Tocal Project Cosc:

$$
108,200
$$

Estimated Dare(s) of Cumplerion:

B. 1 